\title{
The Effect of the Traditional Board Game "Dam-Daman" on the Elderly Cognitive Functions at the Elderly Integrated Health Center, Pegongsoran, Pemalang District, Pemalang
}

\author{
Devita Elsa Arum Masruroh ${ }^{1}$, Nur Isnaini ${ }^{2}$ \\ ${ }^{1,2}$ Department of Health, Universitas Muhammadiyah Purwokerto, Indonesia
}

\begin{tabular}{l} 
ARTICLE INFO \\
\hline Article history: \\
DOI: \\
10.30595/pshms.v2i.234 \\
Submitted: \\
December 6, 2021 \\
Accepted: \\
January 21, 2022 \\
Published: \\
January 26, 2022 \\
\end{tabular}

\section{Keywords:}

Traditional board game of damdaman; Elderly; Cognitive function

\begin{abstract}
The rising number of elderly is due to an increase in life expectancy. However, this can cause a number of illnesses, for example impaired cognitive function. Then, some efforts wear done to maintain cognitive function in the elderly, such as by increasing brain-stimulating avtivities. In particular, the traditional board game of dam-daman is one of the nonpharmacological therapies to inhibit the decline in cognitive function. The objective of this study was to determine the effect of the traditional board game of dam-daman on the cognitive fuction of the elderly at the Elderly Integrated Health Center, Pegongsoran, Pemalang District, Pemalang.This study used a quasi-eksperimental pretest-posttest research design with control group design. The sampling technique of the study was random sampling in which 32 elderly people were selected. In addition, MMSE was employed as the research instrument an Independent Sample T-Test was used to analyze the data.The results showed that the majority of respondents neither went to school and finished elementary school. Most of them did physical activities for daily activities. The MMSE score indicated that the elderly who received the intervention (traditional board game of dam-daman) obtained a significan increase of brain-stimulating activities compared to them who did not.The results of the Independent Sample T-Test test obtained an Asymp.Sig value was 0.000 (P value <0.05). So, there was an effect of the traditional board games of dam-daman on cognitive function in the Elderly Integrated Health Center, Pegongsoran, Pemalang District, Pemalang, in which the Kolmogrov-Smirnov test shows that $p$ value is $<0.05$.
\end{abstract}

This work is licensed under a Creative Commons Attribution 4.0 International License.

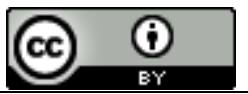

Corresponding Author:

Nur Isnaini,

Department of Health, Universitas Muhammadiyah Purwokerto,

Soepardjo Rustam Street KM. 7, Banyumas, Indonesia

Email: nurisnaini@ump.ac.id

\section{INTRODUCTION}

The rising number of elderly is due to an increase in life expectancy in Indonesia. The increasing life expectancy in the elderly can cause several diseases in the elderly, one of the diseases that often occurs in the elderly is degenerative disease. [1]There are several types of degenerative diseases in the elderly, one of which is changes in the nervous system that manifest in decreased cognitive function. [2]

Cognitive function is a mental process in obtaining knowledge or abilities and intelligence which includes ways of thinking, memory, understanding, planning, and implementation. [3] Cognitive function normally declines with age. Risk factors that can affect cognitive function decline include age, gender, education level, lifestyle (including diet, physical activity and stress.[4]

According to research conducted which was conducted on elderly dementia with diabetes, the results showed that the impact on cognitive impairment of dementia for the lives of the elderly was a lack of confidence, shame, worry about changing roles where the patient could not be independent and still needed 
help. others in performing daily activities. Thus, efforts need to be made to maintain cognitive function in the elderly.[5]

Efforts can be made to maintain cognitive function in the elderly by increasing activities that can stimulate the brain. Based on research conducted on the effect of chess game (chess game) on comfortable (cognitive) thoughts in elderly dementia, the results showed that the chess game intervention (chess game) increased comfortable (cognitive) thoughts in the elderly. [6] Other research also shows that doing activities that can stimulate the brain, such as reading, writing, playing puzzles, playing chess, playing cards, group discussions, and playing music, in the elderly can inhibit the process of memory loss. [1]

Activities that can be done to stimulate cognitive is by playing board games. Board games (board games) is also beneficial to delay the decline of cognitive function of elderly and can help the elderly to socialize, interaction with peers. [7]

The traditional game of dam-daman is a game in the form of pawns such as a chessboard that can be played on boards, paper, or anything using pawns such as pebbles or tile fragments. [8] This game is played by 2 players, each player has 16 pawns. [9] The way to play is that each pawn moves forward to attack the opponent by jumping on it and occupying an empty place. The winner is the player who has the most pawns. [10]

The board game can be categorized as a cognitive activity because it trains concentration, increases creativity in developing game strategies and problem solving. [8] Cognitive activity will stimulate the brain, improve the relationship between brain cells, improve brain compensation for pathology by increasing brain reserves so that in the end it will protect / slow down the clinical onset of cognitive disorders in the elderly. [11]

The results of a preliminary study on November 5, 2020 at the elderly integrated health center, Pegongsoran, Pemalang District, Pemalang using a Mini Mental Status Examination (MMSE) questionnaire sheet for 10 elderly people, showed 5 elderly had mild cognitive impairment with a score of 21, 19, 22, 18, 20. and 5 elderly experienced severe cognitive impairment with a score of $9,13,15,13,12$. This condition resulted in disrupted activities of the elderly, just staying at home. This can accelerate the decline in cognitive function of the elderly. The dam-daman game can be applied to the daily activities of the elderly, considering that the game is easy to play, and can preserve traditional games that have been abandoned for a long time.

Based on this description, researchers are interested in conducting research on "the influence of the traditional board game of dam-daman on the cognitive function of the elderly in elderly integrated health center, Pegongsoran, Pemalang District, Pemalang ".

\section{METHOD}

This research uses quantitative method with Quasy Experiment Pretest-Posttest with Control Group Design. The population in this study was 35 people, the sample used was 16 elderly people aged 60-74 years (elderly) from the total population as the intervention group and 16 elderly people aged 60-74 years (elderly) as a control group. This research was conducted at the elderly integrated health center, Pegongsoran, Pemalang District, Pemalang.

The sampling technique used is the simple random sampling method. In this study, the Mini Mental State Examination (MMSE) questionnaire was used.

Data analysis used is univariate analysis to determine the frequency distribution of respondent characteristics (education and daily activities), and bivariate analysis to compared the mean post-test difference of the experimental group and the control group. Data analysis used independent sample t test because the data were normally distributed with a significance value $>0.05$.

\section{RESULTS AND DISCUSSION}

3.1.Univariat

Tabel 1. Distribution of Respondents Characteristics

\begin{tabular}{lcccc}
\hline \multirow{2}{*}{ Education } & \multicolumn{2}{c}{ Intervention Group $(\mathbf{n = 1 6})$} & \multicolumn{2}{c}{ Control Group (n=16) } \\
\cline { 2 - 5 } & $\mathbf{n}$ & $\mathbf{\%}$ & $\mathbf{n}$ & $\mathbf{\%}$ \\
\hline No school & 10 & 62.5 & 6 & 37.5 \\
ES & 6 & 37.5 & 10 & 62.5 \\
Daily activities & & & & \\
Stay at home & 5 & 31.25 & 4 & 25.00 \\
Doing physical activity & 11 & 68.75 & 12 & 75.00 \\
& & & & \\
\hline
\end{tabular}


Based on table 1 above, it is known that that the education of the majority of respondents did not go to school and finished elementary school, and the daily activitiesoftheelderlydophysicalactivities.

\subsection{Bivariat}

Table 2. Overview of MMSE Intervention Group

\begin{tabular}{cccccc}
\hline \multirow{2}{*}{ No } & \multicolumn{5}{c}{ Ability Level } \\
\cline { 2 - 5 } & \multicolumn{5}{c}{ Intervention Group } \\
\cline { 2 - 5 } 1 & Pre-Test & 1 & 2 & 3 & 4 / Post-Test \\
2 & 17 & 22 & 23 & 23 & 23 \\
3 & 22 & 23 & 26 & 27 & 21 \\
4 & 16 & 19 & 19 & 20 & 28 \\
5 & 19 & 23 & 27 & 27 & 28 \\
6 & 22 & 26 & 27 & 28 & 25 \\
7 & 16 & 17 & 21 & 24 & 26 \\
8 & 15 & 16 & 17 & 20 & 28 \\
9 & 18 & 20 & 22 & 25 & 26 \\
10 & 22 & 26 & 27 & 27 & 26 \\
11 & 19 & 18 & 25 & 25 & 30 \\
12 & 16 & 23 & 19 & 21 & 20 \\
13 & 17 & 26 & 24 & 24 & 21 \\
14 & 22 & 17 & 28 & 30 & 27 \\
15 & 15 & 18 & 20 & 20 & 20 \\
16 & 14 & 23 & 19 & 21 & 30 \\
Min & 19 & 16 & 26 & 26 & 24,88 \\
Max & 14 & 26 & 17 & 20 & 30 \\
Mean & 18 & 21,19 & 23,13 & 24,25 & \\
\hline
\end{tabular}

Table 3. Overview of MMSE Intervention Group

\begin{tabular}{cccccc}
\hline & \multicolumn{5}{c}{ Ability Level } \\
\cline { 2 - 5 } No & \multicolumn{5}{c}{ Control Group } \\
\cline { 2 - 5 } & Pre-Test & 1 & 2 & 3 & / Post-Test \\
\hline 1 & 22 & 22 & 22 & 22 \\
3 & 22 & 22 & 22 & 22 & 16 \\
4 & 16 & 16 & 16 & 16 & 18 \\
5 & 18 & 18 & 19 & 18 & 21 \\
6 & 21 & 21 & 21 & 21 & 20 \\
7 & 22 & 22 & 22 & 22 & 15 \\
8 & 15 & 15 & 15 & 15 & 22 \\
9 & 22 & 22 & 22 & 22 & 16 \\
10 & 21 & 21 & 21 & 21 & 16 \\
11 & 16 & 16 & 16 & 16 & 19 \\
12 & 16 & 16 & 20 & 16 & 16 \\
13 & 20 & 20 & 16 & 20 & 19 \\
14 & 16 & 16 & 20 & 16 & 20 \\
15 & 20 & 20 & 21 & 19 & 17 \\
16 & 21 & 21 & 17 & 21 & 15 \\
Min & 17 & 16 & 15 & 17 & 22 \\
Max & 15 & 15 & 22 & 15 & 18,75 \\
Mean & 22 & 22 & 19,13 & 22 & 19,00 \\
\hline
\end{tabular}

Based on table $2 \& 3$ above, it is known that that of the MMSE Pre-test measurement results in the intervention group and control group show the minimum value in the intervention group 14 and control group 15 , the maximum value in the intervention group and control group is 22 , the mean value in the intervention group is 18.06 and the control group is 18.06. control 19.06. 
Table 4. Pre-Test Cognitive Functions of Respondents in the Intervention Group and the Control Group

\begin{tabular}{lcccc}
\hline \multicolumn{1}{c}{ Pre-Test Cognitive Function } & \multicolumn{2}{c}{ Intervention Group $(\mathbf{n}=\mathbf{1 6})$} & \multicolumn{2}{c}{ Control Group $(\mathbf{n}=\mathbf{1 6})$} \\
\cline { 2 - 5 } & $\mathbf{n}$ & $\mathbf{\%}$ & $\mathbf{n}$ & $\mathbf{\%}$ \\
\hline Mild Cognitive Disorder & 8 & 50,00 & 10 & 62,5 \\
Severe Cognitive Disorder & 8 & 50,00 & 6 & 37,5 \\
\hline
\end{tabular}

Based on table 4, it shows that the results cognitive function of respondents before (pre-test) was given the game of dam-daman in the intervention group, namely the elderly with mild cognitive impairment as many as 8 elderly (50.00\%), and the elderly with severe cognitive impairment as many as 8 elderly $(50.00 \%)$. Cognitive function in the control group, namely the elderly with mild cognitive impairment as many as 10 elderly (62.5\%), and the elderly with severe cognitive impairment as many as 6 elderly (37.5\%).

Table 5. Post-Test Cognitive Functions of Respondents in the Intervention Group and the Control Group

\begin{tabular}{lcccc}
\hline \multirow{2}{*}{ Post-Test Cognitive Function } & \multicolumn{2}{c}{ Intervention Group $(\mathbf{n = 1 6})$} & \multicolumn{2}{c}{ Control Group $(\mathbf{n = 1 6})$} \\
\cline { 2 - 5 } & $\mathbf{n}$ & $\mathbf{\%}$ & $\mathbf{n}$ & $\mathbf{\%}$ \\
\hline Mild Cognitive Disorder & 6 & 37,5 & 10 & 62,5 \\
Severe Cognitive Disorder & 0 & 0,00 & 6 & 37,5 \\
Normal & 10 & 62,5 & 0 & 0,00 \\
\hline
\end{tabular}

Based on table 5, it shows that the results cognitive function of respondents after (post-test) was given the game of dam-daman in the intervention group, namely the elderly with mild cognitive impairment as many as 6 elderly (37.5\%), elderly with normal cognitive as many as 10 elderly (62.5\%). Cognitive function in the control group, namely the elderly with mild cognitive impairment as many as 10 elderly $(62.5 \%)$, and the elderly with severe cognitive impairment as many as 6 elderly $(37.5 \%)$.

Table 6. Independent Simple T-Test

\begin{tabular}{ccccc}
\hline \multirow{2}{*}{ MMSE Results } & \multicolumn{2}{c}{ Independent Sample T-Test } & \\
\cline { 2 - 5 } & $\mathbf{t}$ & $\mathbf{d f}$ & Sig (2tailed) & Information \\
\hline Equal variances assumed & 4.211 & 30 & 0,000 & There is an effect \\
\hline
\end{tabular}

Based on table 6, it shows that the results the results of the Independent Sample T-Test in this study, the Asymp.Sig value ( 2 tailed) or value (P Value $0.000<0.05)$, there was a difference in the mean of the posttest results of cognitive function between groups.

\subsection{The effect of traditional board game of dam-daman on cognitif function}

The results of the Independent Sample T-Test in this study, the Asymp.Sig value (2 tailed) or value ( $\mathrm{P}$ Value $0.000<0.05$ ), there was a difference in the mean of the post-test results of cognitive function between groups. intervention with the control group, it can be concluded that Ho is rejected, which means that there is an influence of the traditional board game of dam-daman on the cognitive function of the elderly in the elderly integrated health center, Pegongsoran, Pemalang District, Pemalang.

The increase in the MMSE score was caused by the enthusiasm of the elderly and the willingness to learn new things for brain health, namely the cognitive activity of the Dam-Daman Traditional Board Game. These cognitive activities will stimulate the brain by providing adequate stimulation to maintain and improve the remaining cognitive functions of the brain. The remaining cognitive functions in the brain will work when making decisions, processing, and answering questions in the game, and the brain will work in retaining the message or information obtained.

The difference in MMSE scores in the intervention group was greater than that in the control group. The results of this study are in accordance which states that a given game intervention can improve cognitive function. [12] This increase in cognitive function is obtained because the traditional board game of damdaman makes both hemispheres able to function optimally simultaneously so that they will achieve high thinking and creativity skills by training the brain's ability which in turn can improve cognitive by providing adequate stimulation to maintain and improve cognitive function of the brain. [11]

The results of this study are in accordance which states that brain stimulation occurs when sensory input is processed by the association cortex, cortical neurons send impulses to the medial temporal lobe which includes the hippocampus and the surrounding temporal cortex area. The prefrontal cortex and medial temporal lobe receive input from acetycholine-releasing neurons located at the base of the forebrain. This acetylcholine spark is thought to allow the formation of a memory. The loss of acetylcholine input released by the brain's basal neurons can interfere with the process of forming new memories and retrieving old 
memories. The results showed that there was an increase in the MMS score in the elderly who received the intervention, experiencing a significant increase with a significant $p$ value of $0.000(p<0.05)$. [13]

The therapy playing the traditional board game of dam-daman does not exhaust much energy and mind because it is packaged in the form of a fun game, it makes the brain relax but there is still cognitive activity that is being carried out so that it can foster enthusiasm and the elderly become happy after playing. Play therapy can also improve memory and smooth brain function, improve concentration and memory as well as playing traditional board games of dam-daman can be done in free time with family members and other elderly without having an instructor.

The traditional board game of dam-daman in this study is a form of cognitive activity which can be concluded that it can affect cognitive function. The results of this study are in accordance with research conducted that cognitive activity can stimulate the brain thereby increasing cognitive and brain reserves with a significant value of $0.000(\mathrm{p}<0.05)$. [14] Research conducted that memory will be recalled if the same set of neurons as those involved in memory formation are stimulated so as to increase the cognitive abilities of the elderly with a $95 \%$ significance, the significant value is 0.007 or less than the significant value 0,05 .[15]

The traditional board game of dam-daman stimulates the cognitive function of the elderly because it has certain points that can stimulate the cognitive aspects of the elderly such as orientation, registration, calculation, remembering and language. After playing the traditional board game and the losing players will be asked questions on orientation aspects such as the name of the place and time, in addition to the calculation aspect it is influenced by asking questions at the end of the game such as addition and subtraction. The aspect of remembering is influenced by stimulating the elderly to remember the dam-daman game, when and where they last played, and remembering the rules of the game. The language aspect is influenced by providing stimulation, the intervention of traditional board games and socializing with opponents, the fluency of the elderly in giving orders and the ability of the elderly to repeat the commands that have been given. The board game then activates parts of the brain, namely in the hippocampus and enrohial cortex by producing the neurotransmitter acetylcholine which is able to improve cognitive and prevent dementia with a significant value of $0.001(\mathrm{p}<0.05)$. [16]

The importance of the neurotransmitter acetylcholine was revealed in a study conducted that the neurotransmitter acetylcholine (ACh) regulates various physiological processes throughout the body, whereas acetylcholine $(\mathrm{ACh})$, the first neurotransmitter to be identified, mediates cell-to-cell communication in the central nervous system. and peripheral, and non-neuronal systems. Cholinergic neurons in this group project widely across cortical and subcortical domains, consistent with their involvement in complex brain functions, including attention, perception, associative learning, and sleep balance. Dysregulation of central cholinergic transmission is associated with a number of brain disorders, including Alzheimer's disease, addiction, epilepsy, Parkinson's disease, schizophrenia, and depression. In both the nervous and non-peripheral nervous systems, acetylcholine (ACh) is released by both neurons and non-neuronal cells to convey rapid transmission at the neuromuscular junction and to regulate the function of various other tissues and organs, including the heart, liver, and pancreas.[17]

\section{CONSLUSIONS}

Based on the results of the study, the majority of the respondents' last education level were the elderly who did not go to school and elementary school, and the majority of the elderly's daily activities did physical activity. The results of the study of the elderly at the elderly integrated health center, Pegongsoran, Pemalang District, Pemalang, the mean MMSE value before the intervention was carried out was 18.06 in the experimental group and 19.06 in the control group, while the mean MMSE value after the dam-daman game intervention was $4 \mathrm{x}$ in 2 week was 21.19 in the experimental group and 19.00 in the control group. the results obtained are $0.200,0.179,0.075,0.128$ or $\mathrm{p}$ value $>0.05$ which means all. The results of the Independent Simple T-Test in this study obtained the Asymp.Sig value (2 tailed) or the value (P Value $0.000<0.05$ ), which means that there is an influence of the traditional board game of dam-daman on the cognitive function of the elderly at the elderly integratedhealthcenter, Pegongsoran, Pemalang District, Pemalang.

\section{Acknowledgements}

Thank you to Allah SWT, both parents and all comrades in arms who have helped from beginning to end. 


\section{REFERENCES}

[1] A. Madianung, “Aktivitas Bermain Domino Sebagai Media Untuk Meningkatkan Kemampuan Fungsi Kognitif Berhitung Pada Lansia,”Jurnal Keperawatan, vol. 7, no. 1, p. 1-8, 2019.

[2] M.D. Iswara, D.R. Dewi, \& S.N.Yanti, "Gambaran fungsi kognitif pada lansia di Posyandu Lansia Kelurahan Banjar Serasan Kecamatan Pontianak Timur tahun 2015,” Media Konservasi, vol. 2, no. 1, p. 11-4, 2016.

[3] C.H. Manurung, W. Karema, \& J. Maja, "Gambaran fungsi kognitif pada lansia di Desa Koka Kecamatan Tombulu," E-Clinic, vol. 4, no. 2, p. 2-5, 2016.

[4] I.A. Rasyid, Y. Syafrita \& S. Sastri “Artikel penelitian hubungan faktor risiko dengan fungsi kognitif pada lanjut usia Kecamatan Padang Panjang Timur Kota Padang Panjang,” vol. 6, no. 1,p. 49-54, 2017.

[5] T. Santos, J. Lovell, K. Shiell, M. Johnson, \& J.E. Ibrahim, "The impact of cognitive impairment in dementia on self-care domains in diabetes: A systematic search and narrative review, Diabetes/Metabolism Research and Reviews," vol. 34, no. 6, 2018.

[6] A.W.L.Wildan, J. Haryanto, \& K. Bahiyah, "Pengaruh chess game (permainan catur) terhadap pikiran nyaman (kognitif) pada lansia demensia," Jurnal Keperawatan, vol. 9, no. 2,p. 63-70, 2016.

[7] M. Rozikin, "Pengaruh permainan uno stacko terhadap peningkatan fungsi kognitif lansia di Griya Usila Santo Yosef Surabaya," Universitas airlangga, 4, 9-15, 2017.

[8] Iswinarti, Permainan Tradisional, Prosedur dan Analisis Manfaat Psikologis, Malang : Universitas Muhammadiyah Malang, 2017.

[9] P. Irwan, Direktori Permainan Tradisional Kabupaten Banyuasin-Sumatera Selatan, Sumatera Selatan : Dinas Pendidikan, Pemuda, Olahraga, dan Pariwisata, 2019.

[10] M. Aisha, "Pengaruh permainan dam-daman terhadap kapasitas visuospatial working memory pada siswa kelas 4 sekolah dasar,"Universitas Pancasila, vol. 23, no.3, p. 1-9, 2019.

[11] B.R.Wreksoatmodjo, “Aktivitas kognitif mempengaruhi fungsi kognitif lanjut usia di Jakarta," Cdk224,vol. 42, no. 1, p. 7-13, 2015.

[12] W.A. Romadhon, "Pengaruh permainan tradisional dam-daman terhadap penurunan tingkat demensia pada lansia di kabupaten kediri," Universitas Arilangga, 2016.

[13] D.N. Nawangsari, "Pengaruh terapi puzzle terhadap tingkat demensia lansia di Wilayah Krapakan Caturharjo Pandak Bantul," Jurnal Kesehatan, p. 1-17, 2016.

[14] S.A. Marcello, "Pengaruh boardgame (puzzle) terhadap fungsi kognitif lansia di Panti Werdha,"Universitas Katolik Widya Mandala Surabaya, 2019.

[15] Yusti, Dkk, “Aktivitas bermain domino sebagai media untuk meningkatkan kemampuan fungsi kognitif berhitung pada lansia (Domino play activities as a media to improve the ability to calculate cognitive functions in the elderly)," E-Journal Keperawatan, vol. 7,no. 1, 2019.

[16] Y. Ching-Teng, "Effect of board game activities on cognitive function improvement among older adults in adult day care centers,"Social Work in Health Care, vol. 58, no.9 , 825-838, 2019.

[17] Jing \& L.W. Langma, "Indikator asetilkolin fluoresen yang dikodekan secara genetika untuk studi in vitro dan in vivo,"Nature biotechnology, vol. 36, no. 8, 726-737, 2018. 